\title{
Mediterranean basin-wide correlations between Saharan dust deposition and ocean chlorophyll concentration
}

\section{R. Gallisai ${ }^{1}$, F. Peters ${ }^{1}$, S. Basart ${ }^{2}$, and J. M. Baldasano ${ }^{2,3}$}

${ }^{1}$ Departament de Biologia Marina i Oceanografia, Institut de Ciències del Mar, CSIC, 08003 Barcelona, Catalunya, Spain

${ }^{2}$ Earth Sciences Department, Barcelona Supercomputing Center-Centro Nacional de Supercomputación, BSC-CNS, Barcelona, Catalunya, Spain

${ }^{3}$ Environmental Modelling Laboratory, Technical University of Catalonia, Barcelona, Spain

Received: 19 June 2012 - Accepted: 25 June 2012 - Published: 17 July 2012

Correspondence to: R. Gallisai (gallisai@icm.csic.es)

Published by Copernicus Publications on behalf of the European Geosciences Union.
Saharan dust

deposition and ocean chlorophyll concentration

R. Gallisai et al.

\section{Title Page}

Abstract

Conclusions

Tables

14

4

Back
Introduction

References

Figures

$>$ I

$>$

Close
Full Screen / Esc

Printer-friendly Version

Interactive Discussion 


\section{Abstract}

The fertilizing potential of atmospheric deposition on ocean production in the Mediterranean is a matter of debate. In this study, eight years (from 2000 to 2007) of weekly chlorophyll concentration data derived from SeaWiFS satellite observations and dust

5 deposition data provided by the BSC-DREAM8b model are investigated in a basin-wide scale in the Mediterranean Sea to describe the geographical distribution and dynamics of both variables and to find potential relationships between them.

In all analyses the largest positive cross correlation values are found with a time lag of 0 8-d periods. The coupling between annual cycles of chlorophyll and dust deposition may on average explain an $11.5 \%$ in chlorophyll variation in a large part of the Mediterranean. The Eastern Mediterranean shows the largest annual correlations, while the responsiveness to large events is small. The contrary is true for the Western and Northwestern Mediterranean where, if anything, only large events may add to the chlorophyll variability. The Central Mediterranean shows the highest responsive-

variability as well as stimulations owing to large events.

These results highlight the importance of dust deposition from African and Middle East origin in the potential stimulation of phytoplankton production in the nutrient depleted surface layers of the Mediterranean Sea.

\section{Introduction}

The atmosphere and the ocean are dynamic compartments within the Earth system that are constantly interacting with each other. In addition to exchanges of thermal and mechanical energy, ocean and atmosphere exchange a multitude of chemical compounds such as gases and particulate matter that have effects on global biogeochemical cycles and are highly variable in space and time (Bonnet et al., 2005).

BGD

$9,8611-8639,2012$

\section{Saharan dust \\ deposition and ocean chlorophyll concentration}

R. Gallisai et al.

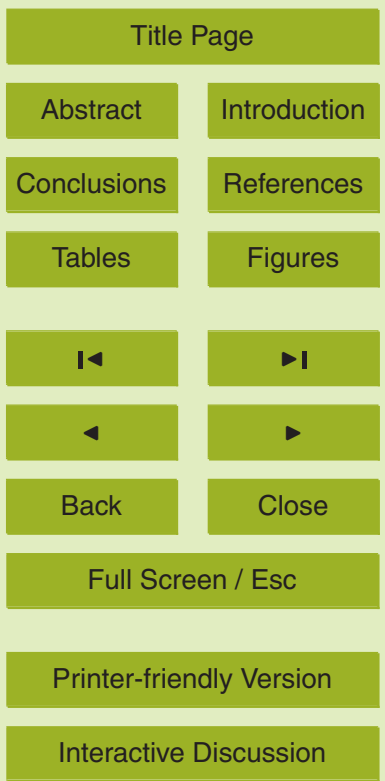


Atmospheric dust deposition supplies several macronutrients, such as phosphorus (Bergametti et al., 1992; Migon and Sandroni, 1999; Ridame and Guieu, 2002; Markaki et al., 2003; Guieu et al., 2010; Pulido-Villena et al., 2010), nitrogen (Loÿe-Pilot et al., 1990; Herut et al., 1999; Kouvarakis et al., 2001; Bonnet et al., 2005; Sandroni et 5 al., 2007; Markaki et al., 2010), iron (Bonnet and Guieu, 2006; Theodosi et al., 2010) and silicate (Moreno et al., 2006) to the surface waters of the Mediterranean Sea.

The Mediterranean Basin is considered one of the most oligotrophic marine ecosystems on Earth (Béthoux et al., 1998). During the stratification period, the phytoplankton community is strongly limited by nutrients. In general, it seems that the strongest limit10 ing nutrient is phosphorus, followed by nitrogen (Estrada, 1996; Thingstad et al., 2005). On the other hand, the Mediterranean atmosphere is subject to a continuous presence of Saharan mineral dust particles (Barnaba and Gobbi, 2004; Antoine and Nobileau, 2006; Engelstaedter et al., 2006). The deposition on surface waters of these particles and soluble compounds, rich in nutrients, may influence biological production. The contribution through atmospheric deposition of nitrogen and phosphorus in the Mediterranean Sea has been shown to be significant (Guerzoni et al., 1999; Migon and Sandroni, 1999; Guieu et al., 2002a, b; Markaki et al., 2003; Morales-Baquero et al., 2006a), at least during certain events. Therefore, atmospheric deposition is a major potential source through which "new" nutrients, essential for primary production, are deposited on Mediterranean surface waters (Ternon et al., 2011).

Despite the potential contribution of atmospheric nutrients to marine production, evidence of direct effects is hard to find and results are unclear. Previous studies on the effect of Saharan dust inputs on phytoplankton have been restricted to a few specific areas in the Mediterranean basin, having provided contrasting estimates. Different amendment experiments have shown fertilization effects of Saharan dust on both heterotrophic and autotrophic communities (Klein et al., 1997; Ridame and Guieu, 2002; Bonnet et al., 2005; Eker-Develi et al., 2006; Pulido-Villena et al., 2008; Lekunberri et al., 2010; Romero et al., 2011; Ternon et al., 2011). On the other hand, Volpe et
BGD

9, 8611-8639, 2012

\section{Saharan dust \\ deposition and ocean chlorophyll concentration}

R. Gallisai et al.

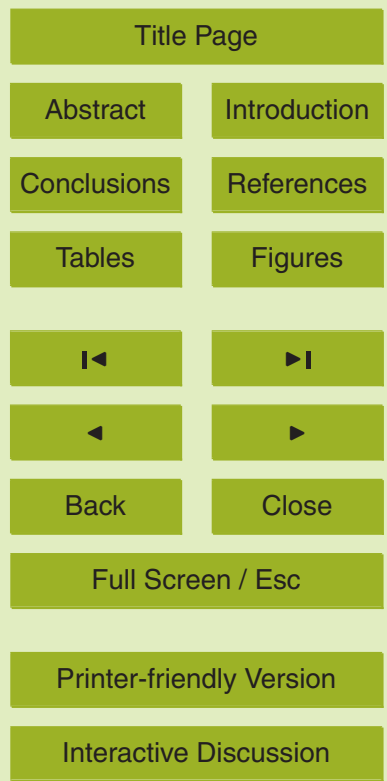


al. (2009) found interferences between satellite-derived aerosol optical thickness data and chlorophyll data masking possible functional relationships between both variables.

Aerosol optical thickness (AOT) is a radiometer-based datum that can be used as a proxy of atmospheric turbidity. It is an estimation of the particle load in the air column.

5 Saharan dust transport over the Mediterranaean shows a seasonal pattern (Moulin et al., 1998; Barnaba and Gobbi, 2004). The peak of transport over the Eastern Mediterranean occurs in spring, in the Central Mediterranean during the spring-summer period, and in the Western Mediterranean during the summer. While in Antoine and Nobileau (2006) the largest AOT values over the Mediterranean Sea were found in the 10 Eastern basin during spring, then this moves to a lower extent in the Western during summer and in Central in autumn. In any case, atmospheric dust load does not necesarily mean deposition over a certain area. In the Mediterranean Basin, transport of desert dust aerosols occurs at different heights (Mona et al., 2006; Papayannis et al., 2008; Sicard et al., 2011). The winter and spring aerosol plumes that cross the

(Pappalardo load tends to travel in higher atmospheric layers reaching $6000 \mathrm{~m}$ in height (Pappalardo et al., 2003; Bartoli et al., 2005; Papayannis et al., 2008). Thus, in order to relate possible effects of aerosols on plankton dynamics, not only atmospheric load is relevant but also whether aerosols are depositing over the sea.

The aim of this study is to find trends between Saharan dust deposition and surface ocean chlorophyll distribution and dynamics in the Mediterranean Sea using correlational analyses with data from eight years (from 2000 and 2007). Based on the analyses, we identify areas were potential fertilization of primary production from deposition seems related to seasonal dynamics and other areas were potential fertilization seems
BGD

9, 8611-8639, 2012

\section{Saharan dust \\ deposition and ocean chlorophyll concentration}

R. Gallisai et al.

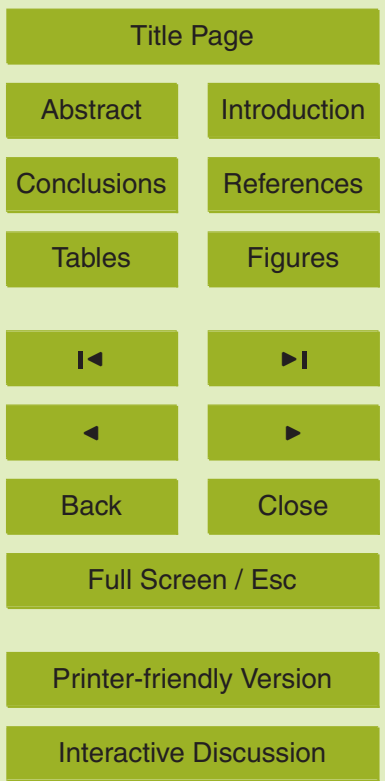




\section{Materials and methods}

\subsection{Chlorophyll}

Chlorophyll concentration data were derived from SeaWiFS (Sea-viewing Wide Fieldof-view Sensor) satellite radiometer measurements. An 8-d averaged, $9 \mathrm{~km}$ resolution

5 product (reprocessing 5) was downloaded from the Giovanni online data system (http: //disc.sci.gsfc.nasa.gov/giovanni). We extracted data for 179 different $1^{\circ} \times 1^{\circ}$ areas in the Mediterranean Sea (Fig. 1), in order to have a wide coverage of the entire basin, from 2000 to 2007.

\subsection{Saharan dust deposition}

10 Saharan dust deposition was obtained from the BSC-DREAM8b model (Pérez et al., 2006a, b). The model simulates or predicts the 3-dimensional field of the dust concentration in the troposphere and takes into account all major processes of dust life cycle, such as dust production, horizontal and vertical diffusion and advection as well as wet and dry deposition. The main features of BSC-DREAM8b, described in detail in

15 Pérez et al. (2006b), are a source function based on the arid and semi-arid categories of the $1 \mathrm{~km}$ USGS land use data set, 8 size bins within the $0.1-10 \mu \mathrm{m}$ radius range according to Tegen and Lacis (1996) are used to describe the size distribution of dust, a source distribution derived from D'Almeida (1987), and the inclusion of dust radioactive feedbacks (Pérez et al., 2006b).

20 In the last years, the model has been used for dust forecasting and as dust research tools in North Africa and the Mediterranean (Amiridis et al., 2009; Alonso-Perez et al., 2011; Pay et al., 2012). Several case studies have outlined the good skills of BSCDREAM8b (Pérez et al., 2006a, b; Papanastasiou et al., 2010) concerning both the horizontal and vertical extent of the dust plume in the Mediterranean Basin. Furthermore, daily evaluation of BSC-DREAM8b with near-real time observations is conducted in BSC-CNS. Currently, the daily operational model evaluation includes satellites (MODIS

\section{Saharan dust \\ deposition and ocean chlorophyll concentration}

R. Gallisai et al.

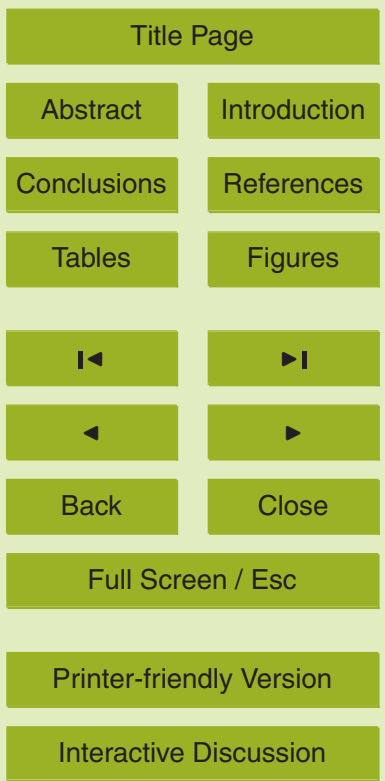


and MSG) and AERONET sun photometers. BSC-DREAM8b has also been validated and tested over longer time periods in the European region (Jiménez-Guerrero et al., 2008; Pay et al., 2010; Basart et al., 2012) and against measurements at source regions for the SAMUM (Haustein et al., 2009) and BODEX campaigns (Todd et 5 al., 2008).

For the present study, a dust simulation of the BSC-DREAM8b model is used for the period between 1 January 2000 and 31 December 2007 over the Mediterranean basin. The resulting daily-accumulated dust deposition fields have been bilineally interpolated to the chlorophyll grid. $\mathrm{A} 1^{\circ} \times 1^{\circ}$ grid between $31^{\circ} \mathrm{N}$ and $44^{\circ} \mathrm{N}$ and $5^{\circ} \mathrm{W}$ and $35^{\circ} \mathrm{E}$ was used to extract data for the same 179 areas as for chlorophyll.

A low cut-off threshold is applied to the numerical deposition output from BSCDREAM8b since the dataset showed numerically correct but physically unrealistic low value spikes. Highest deposition rates have been reported in the Eastern Mediterranean (Mamane et al., 1982; Pye, 1992; Kubilay et al., 2000; Singer et al., 2003). Furthermore, minimum deposition values are observed in the northern part of the western Mediterranean. Morales-Baquero et al. (2006b) report a minimum of $3 \times 10^{-5} \mathrm{~kg} \mathrm{~m}^{-2} \mathrm{~d}^{-1}$ in Sierra Nevada (southern Spain) over a 3 yr period. Avila et al. (1997) monitored deposition in the Montseny mountains (Northeastern Spain) during $11 \mathrm{yr}$ and the minimum dust deposition was $1.01 \times 10^{-6} \mathrm{~kg} \mathrm{~m}^{-2} \mathrm{~d}^{-1}$. De Angelis and Gaudichet (1991) reported a minimum value of $0.6 \times 10^{-6} \mathrm{~kg} \mathrm{~m}^{-2} \mathrm{~d}^{-1}$ over $30 \mathrm{yr}$ in the Alps region. In order to be on the safe side, we chose a value of $10^{-8} \mathrm{~kg} \mathrm{~m}^{-2} \mathrm{~d}^{-1}$ as the low cut-off threshold for realistic measurable deposition. Finally, daily deposition was log averaged to 8-d periods to match the chlorophyll dataset.

\subsection{Analyses}

25 Pearson's correlation coefficient $(r)$ and the associated $p$-level are calculated between dust deposition and chlorophyll concentration for each of the $1791^{\circ} \times 1^{\circ}$ areas. These analyses are done with and without seasonally detrending one or both variables. Previously, we crosscorrelated chlorophyll and deposition with lags from 0 up to 4 8-d

\section{BGD}

9, 8611-8639, 2012

\section{Saharan dust \\ deposition and ocean chlorophyll concentration}

R. Gallisai et al.

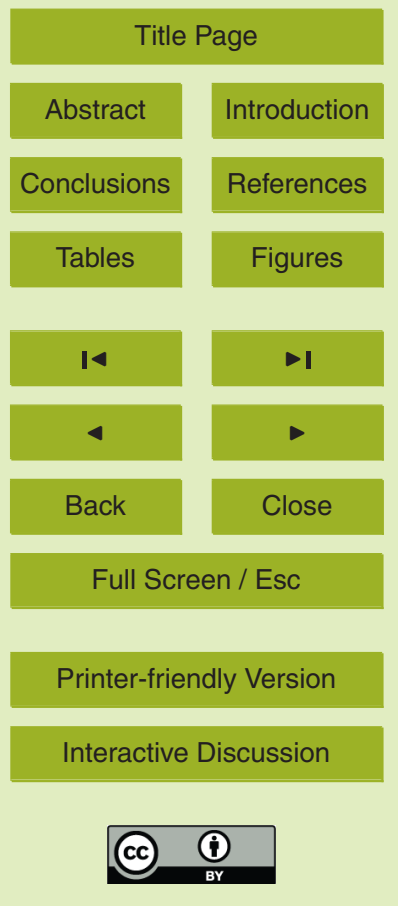


periods to determine that the highest correlations were found with a lag of 0 , that is within a period of 8-d.

\section{Results}

The surface chlorophyll distribution shows both an overall west to east decreasing trend 5 and a south to north increasing trend (Fig. 2a). These trends together with a few local spots of higher chlorophyll concentration (e.g. Alboran Sea, the Tunisian coast, Dardanelle strait and the Northern Adriatic) characterize different biogeographical regions in the Mediterranean (D'Ortenzio and D'Alcalà, 2009). Chlorophyll concentration shows mean concentrations between $0.09 \mathrm{mg} \mathrm{m}^{-3}$ and $0.13 \mathrm{mg} \mathrm{m}^{-3}$ in the southern part of 10 the Eastern basin and between 0.23 and $0.36 \mathrm{mg} \mathrm{m}^{-3}$ in the Northwest Mediterranean. The coefficient of variation (CV) of chlorophyll also shows a major decreasing trend with longitude except for some coastal areas (Fig. 2b). In the Central and Eastern Mediterranean, the chlorophyll CV ranges between $14 \%$ to the $20 \%$ excepting two outlier regions (near the Tunisian coast and in the Dardanelle strait) with CVs higher 15 than $90 \%$. In the Western Mediterranean, the CV of chlorophyll ranges from $20 \%$ to $66 \%$ with the highest CV in areas with the largest mean concentration.

Dust deposition distribution shows a decreasing trend from south to north (Fig. 3a). The highest mean concentration values are present in the southern part of the Mediterranean Sea, with mean values ranging between $5 \times 10^{-7} \mathrm{~kg} \mathrm{~m}^{-2} \mathrm{~d}^{-1}$ and $1 \times$

20 $10^{-7} \mathrm{~kg} \mathrm{~m}^{-2} \mathrm{~d}^{-1}$. On the other hand, the lowest values are located in the northern part of the Mediterranean Sea (North Spain, South France and North Italy), where the range is from $2 \times 10^{-8} \mathrm{~kg} \mathrm{~m}^{-2} \mathrm{~d}^{-1}$ to $3 \times 10^{-8} \mathrm{~kg} \mathrm{~m}^{-2} \mathrm{~d}^{-1}$ in mean concentrations.

In contrast to mean dust deposition values a different scenario is represent for the CV of dust deposition. The CV decreased from north to south (Fig. 3b). The smallest CV in dust deposition occurs in the southern part of the Mediterranean basin where it oscillates between $7 \%$ and $20 \%$. Conversely, in the northern part, we found the highest CV in dust deposition, with values close to $50 \%$.
BGD

9, 8611-8639, 2012

\section{Saharan dust \\ deposition and ocean chlorophyll concentration}

R. Gallisai et al.

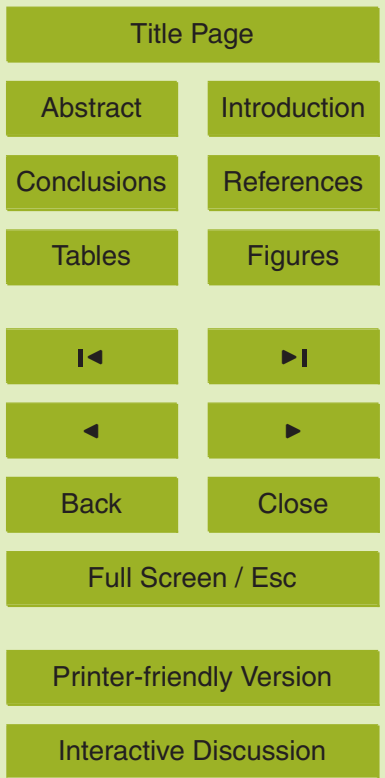


The seasonal trend of deposition shows the largest values in late autumn-winter for the Central and Eastern Mediterranean (Fig. 4), albeit with a lower overall annual variability than in the Northern-Northwestern Mediterranean. The spatial distribution shows larger deposition close to the African and Middle-East sources and a decrease 5 of of average monthly deposition to the Northern Mediterranean.

The correlation between Sahara dust deposition and chlorophyll concentration is shown in Fig. 5a. In the East sub-basin values are between 0.3 and 0.65 , with the exception of the west side of the Nile delta where the correlation coefficient was of 0.18 and the Dardanelle area where it was lower than 0.2. Negative correlations occur in the 10 Southeastern coast of Tunisia, in the Alboran Sea, in the northeastern coast of Spain and in the Gulf of Lions. Furthermore, the Central Mediterranean Sea shows values between 0 and 0.2. The significance of the correlations is shown in Fig. 5b. In most of the Mediterranean basin, the p-levels were lower than 0.05 , with the exception of the Tunisian coast, the Sicily strait, the Northwest Mediterranean and the Northern Adriatic 15 Sea, basically areas that were showing low correlations, either positive or negative. The correlations were non significant, with p-levels close to 1, between the Ligurian coast and the open water in front of the Gulf of Lions and up to the Menorca.

When deposition is correlated with the seasonally detrended chlorophyll (Fig. 6), correlation coefficients show a general drop mostly to values between 0.1 and 0.2 . 20 Three areas show relatively high correlation coefficients (southeast of Sardinia, south of the Balearic islands and south of Sicily). Negative correlation values appear in the Gulf of Lions, in the Alboran Sea, in the southeast coast of Tunisia and in the eastern part of Mediterranean Sea. Even if correlation coefficients are low, all the areas with an $r$ larger than 0.1 are statistically significant. On the other hand, areas showing a 25 negative $r$ are not statistically significant.

Finally, when correlations between deposition and chlorophyll are done after seasonally detrending both data sets (Fig. 7) the results are very similar to the case when only chlorophyll is seasonally detrended. Most areas showed correlation values between 0.1 and 0.2. The highest correlation coefficients were present in the Ionian Sea,
BGD

9, 8611-8639, 2012

\section{Saharan dust \\ deposition and ocean chlorophyll concentration}

R. Gallisai et al.

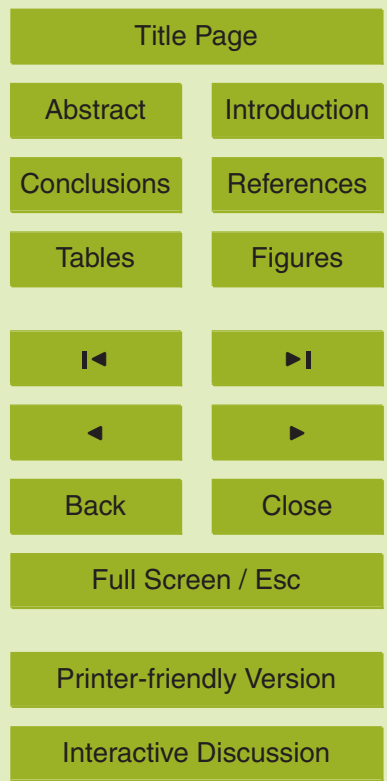


in the south Tyrrhenian and in the northern part of Algeria with values between 0.3 and 0.4. The lowest values appeared in the Gulf of Lions, in the Alboran Sea, in the southeastern coast of Tunisia and in the Levantine Sea, all with a negative correlation coefficient. Again, negative correlation coefficients were not statistically significant. 5 There were 113 areas with p-levels smaller or equal to 0.05 , so only 66 areas showed non-significant correlations.

\section{Discussion}

Previous studies (Bosc et al., 2004; D'Ortenzio and D'Alcalà, 2009) had already evidenced that the Mediterranean is not uniform in surface chlorophyll concentrations 10 and temporal dynamics, and our data is very similar to previous more extensive descriptions. On the contrary, aerosol deposition over the sea is much more difficult or currently impossible to map over time with measurements. There are some point measurements obtained during cruises and some more or less permanent stations that measure mostly aerosols in air and not so much deposition, scattered around the

15 Mediterranean coast and some islands (Querol et al., 2009; Markaki et al., 2010). We have resorted to use synthetic deposition data from an operational aerosol transport model. The BSC-DREAM8b model tracks mineral aerosols from North Africa and Middle East. Other sources, such as of anthropogenic origin and sea spray (Querol et al., 2009), also contribute to aerosols but have not been considered in this study.

The spatial distribution and temporal dynamics of our deposition data shows considerable and more constant deposition rate close to the mineral origin source. A decreasing gradient is present from south to north. In addition, in the North Mediterranean the temporal variability is larger indicating a shift from a more constant annual dynamics to an exposure to large events. Aerosol deposition is favored in the winter and spin the prevailing meteorological conditions make dust plumes travel close to the ocean surface (Alpert et al., 2004). For the remainder of the year, dust plumes in

\section{BGD}

9, 8611-8639, 2012

\section{Saharan dust \\ deposition and ocean chlorophyll concentration}

R. Gallisai et al.

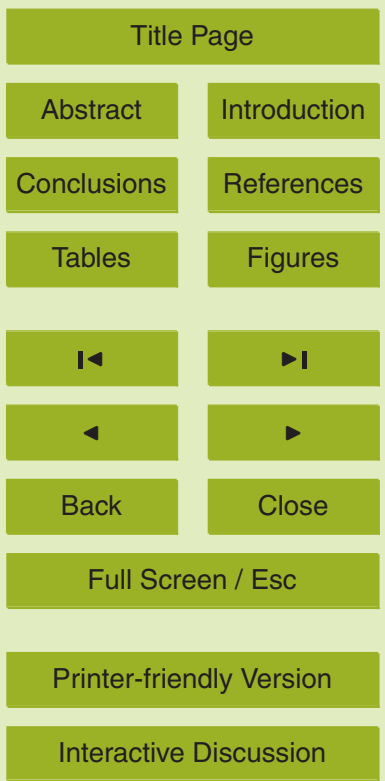


general travel high in the atmosphere over the Mediterranean with reduced chances of deposition over the sea.

Model deposition data seems robust. Papayannis et al. (2008) found a good agreement between lidar observations and BSC-DREAM8b model calculations. Pay et 5 al. (2012) and (Basart et al., 2012) found a good agreement between measured $\mathrm{PM}_{10}$ levels at surface stations and BSC-DREAM8b model calculations. The Saharan dust deposition patterns (seasonal maps) shown in this paper are in a good agreement with Basart et al. (2012). Markaki et al. (2010) observed that the maximum in DIN deposition in the Mediterranean basin was in winter, and about $65 \%$ of DIP deposition occurred in 10 winter as well, in agreement with our modeled deposition data. Dust deposition is subject to large-scale weather features (such as particularly dry years, latitudinal position of the inter-tropical convergence zone, etc.), which can lead to large interannual fluctuations. High deposition rates are also highly dependent on rains, that is, wet deposition (Kubilay et al., 2000; Ridame and Guieu, 2002). Guerzoni et al. (1997) estimated that 15 about 3/4 of Saharan dust is deposited with precipitation. Thus, the annual cycles of deposition show more variability than other variables, but it is clear that these deposition patterns do not completely match AOT data (Moulin et al., 1998; Barnaba and Gobbi, 2004; Antoine and Nobileau, 2006). The fact that we do not consider the deposition of aerosols other than of North African and Middle East mineral origin may also increase the discrepancy between AOT patterns and modeled deposition data.

Surface ocean chlorophyll and dust deposition are highly correlated in the Eastern Mediterranean where it seems that the annual cycles of both variables have a higher match. When seasonally detrended data is used, the correlation is decreased and is mostly non-significant. Thus the Eastern Mediterranean would benefit from a background supply of nutrients from deposition that may fuel the system to some extend while large dust deposition events have a minor role fueling primary production peaks in the area. In the Northwestern Mediterranean deposition tends to be much lower and more event driven, and most likely the higher background water nutrients and chlorophyll levels preclude an effect from deposited material most of the times. A recent

BGD

$9,8611-8639,2012$

\section{Saharan dust \\ deposition and ocean chlorophyll concentration}

R. Gallisai et al.

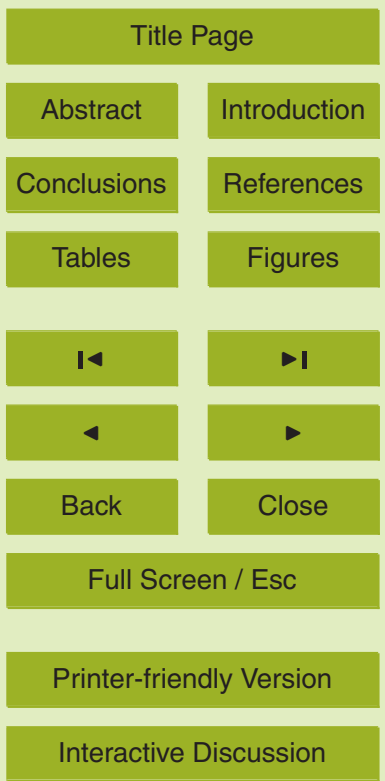


study (Izquierdo et al., 2012) shows that atmospheric-derived $\mathrm{P}$ normally contributes less than $1 \%$ of primary production in the NW Mediterranean but occasional events may contribute up to a $30 \%$ of annual new production.

The Central Mediterranean, taken here loosely between $10^{\circ} \mathrm{E}$ and $20^{\circ} \mathrm{E}$, stands out 5 as an area where both the relatively high background deposition can add to the fueling of the system over the annual cycle and where single large events may also alter significantly the dynamics of chlorophyll. There are 95 areas, coinciding mostly with the Central Mediterranean, where correlations between deposition and chlorophyll are significant when using seasonally detrended as well as and non-detrended data 10 (Fig. 8). In these areas the coupling between annual cycles of both variables was responsible of $11.5 \%$ of the annual chlorophyll variability. Moreover, if we detrended the seasonal patterns of both variables, dust deposition events were responsible for $4.6 \%$ of the variability in chlorophyll. We could distinguish three different zones: one between the Balearic islands and the north African coast, one corresponding to the Tyrrhenian 15 Sea and one corresponding to the Central Mediterranean proper, between Southern Italy, Sicily and the Libyan coast. South of the Balearic Islands and the Tyrrhenian Sea lie the areas most susceptible of event-driven dust deposition, explaining $6 \%$ of the seasonally-detrended variability in chlorophyll. The Central Mediterranean proper is where the annual matching between deposition and chlorophyll explains on average the largest proportion in chlorophyll variability, 19\% (Table 1).

As mentioned earlier, crosscorrelations between dust deposition and chlorophyll show its maximum at lag 0 , that is, within the first $8-d$, as was also found by Volpe et al. (2009) for AOT and chlorophyll. Because of the potential signal interference of AOT with chlorophyll reported by these authors we shy away from a higher temporal resolution that may give spurious correlations. In the areas where our correlations are significant, the absolute correlation values do not exceed 0.65 at the most. This means that the relationship would explain a maximum of $42 \%$ of the temporal variation in chlorophyll, and in most cases around $2 \%$. Of course, nutrients being fueled from rich bottom waters, either through a large annual overturning or through more steady
BGD

9, 8611-8639, 2012

\section{Saharan dust \\ deposition and ocean chlorophyll concentration}

R. Gallisai et al.

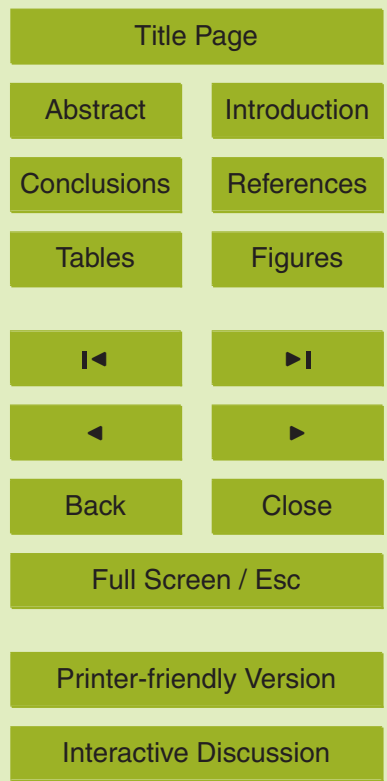


diffusion, is the main driver of phytoplankton in the upper layers. The load of nutrients added through atmospheric deposition at a certain time tends to be small compared to the enrichment from bottom waters, and thus significant correlations, even is small, are highly relevant. In addition it has to be taken into account that small nutrient additions 5 in oligotrophic waters tend to favor first competing bacteria (Pulido-Villena et al., 2008; Lekunberri et al., 2010; Marañón et al., 2010; Romero et al., 2011) and that phytoplankton should then respond to the recycled nutrients. Thus, even in experiments, while responses in activity occur, it is not always straightforward to see responses at the biomass level. Finally, we have only considered deposition of North African and 10 Middle East, mineral sources while we expect that at least in some cases, in some areas or for some events the contribution of other sources, for instance of anthropogenic origin, may also explain part of the seasonally-detrended chlorophyll series.

\section{Conclusions}

An eight years (2000-2007) analysis of SeaWIFS and BSC-DREAM8b model data, 15 shows that mineral dust deposition from North African and Middle East desert dust sources correlates with chlorophyll in fairly large areas of the Mediterranean. This is especially true for the Eastern Mediterranean where aerosol deposition dynamics matches chlorophyll annual dynamics and the atmospheric input may be an intrinsic part of ecosystem dynamics. However, the Eastern Mediterranean shows little respon-

siveness to large dust outbreaks, perhaps because they travel over this area to distances further away. For most of the Western Mediterranean a coupling between the dynamics of both variables is weak or inexistent. This seems to be due to the presence of some relatively rich hot spot areas such as the Gulf of Lions and the Alboran Sea, where other factors are mostly in control of nutrient and chlorophyll dynamics. Only in the South Tyrrhenian and in the northern part of Algeria, a positive connection between the dust outbreaks and chlorophyll is present. Overall, the area most responsive to dust deposition is the Central Mediterranean, with both an annual match in the timings and
BGD

9, 8611-8639, 2012

\section{Saharan dust \\ deposition and ocean chlorophyll concentration}

R. Gallisai et al.

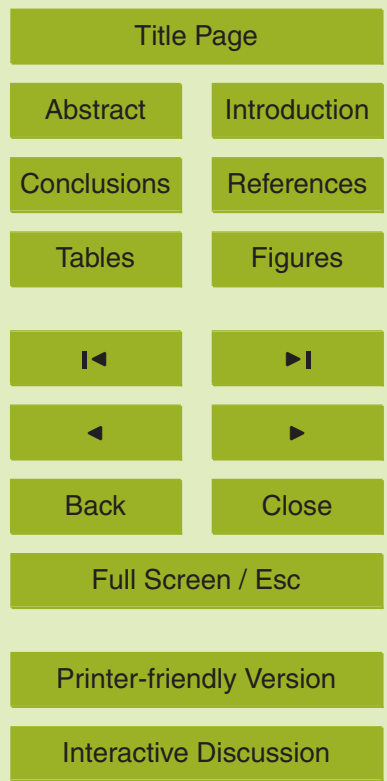


a response to dust outbreaks. It is possible that previous studies between chlorophyll and aerosols in air showed less obvious correlations because not all aerosols in the atmosphere are depositing and many aerosol plumes travel at great heights during most of the year with little chance of deposition.

5 Acknowledgements. SeaWIFS level 3 data of chlorophyll concentration used in this paper were produced with the Giovanni online data system, developed and maintained by the NASA GES DISC. We thank the Goddard Earth Sciences Data and Information Services Center (GES DISC), the SeaWIFS mission scientists and associated NASA personnel for the production of data used in this research effort. BSC-DREAM8b simulations were performed on

10 the MareNostrum supercomputer hosted by the Barcelona Supercomputing Center-Centro Nacional de Supercomputación (BSC-CNS). Maps were produced with Ocean Data View (Schlitzer http://odv.awi.de, 2012). We also acknowledge Marco Talone for help with the data analysis. This study was funded by the Spanish projects STORM (CTM2009-09352) and ADEPT (CTM2011-23458). R.G. is holding a JAE-Predoc fellowship from the CSIC.

Alonso-Perez, S., Cuevas, E., Perez, C., Querol, X., Baldasano, J. M., Draxler, R., and De Bustos, J. J.: Trend changes of African airmass intrusions in the marine boundary layer over the subtropical Eastern North Atlantic region in winter, Tellus B, 63, 255-265, doi:10.1111/j.16000889.2010.00524.x, 2011.

20 Alpert, P., Kishcha, P., Shtivelman, A., Krichak, S. O., and Joseph, J. H.: Vertical distribution of Saharan dust based on 2.5-year model predictions, Atmos. Res., 70, 109-130, doi:10.1016/j.atmosres.2003.11.001, 2004.

Amiridis, V., Kafatos, M., Perez, C., Kazadzis, S., Gerasopoulos, E., Mamouri, R. E., Papayannis, A., Kokkalis, P., Giannakaki, E., Basart, S., Daglis, I., and Zerefos, C.: The potential of the synergistic use of passive and active remote sensing measurements for the validation of a regional dust model, Ann. Geophys., 27, 3155-3164, doi:10.5194/angeo-27-3155-2009, 2009.

\section{BGD}

9, 8611-8639, 2012

\section{Saharan dust \\ deposition and ocean chlorophyll concentration}

R. Gallisai et al.

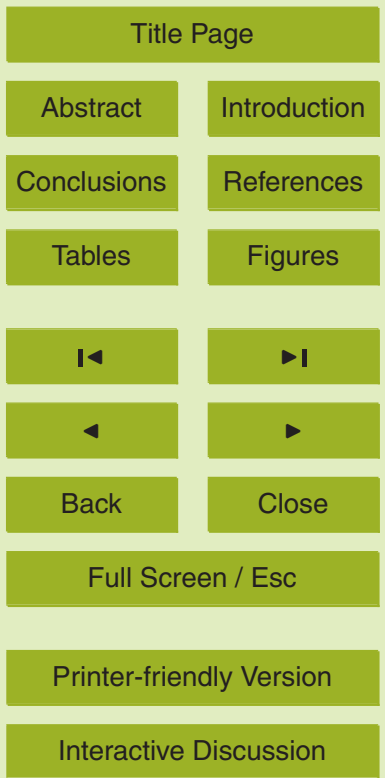


Antoine, D., and Nobileau, D.: Recent increase of Saharan dust transport over the Mediterranean Sea, as revealed from ocean color satellite (SeaWiFS) observations, J. Geophys. Res.-Atmos., 111, D12214, doi:10.1029/2005JD006795, 2006.

Avila, A., Queralt-Mitjans, I., and Alarcón, M.: Mineralogical composition of African dust deliv5 ered by red rains over northeastern Spain, J. Geophys. Res.-Atmos., 102, 21977-21996, doi:10.1029/97JD00485, 1997.

Barnaba, F. and Gobbi, G. P.: Aerosol seasonal variability over the Mediterranean region and relative impact of maritime, continental and Saharan dust particles over the basin from MODIS data in the year 2001, Atmos. Chem. Phys., 4, 2367-2391, doi:10.5194/acp-4-2367$10 \quad 2004,2004$.

Bartoli, G., Migon, C., and Losno, R.: Atmospheric input of dissolved inorganic phosphorus and silicon to the coastal northwestern Mediterranean Sea: Fluxes, variability and possible impact on phytoplankton dynamics, Deep-Sea Res. Pt. I, 52, 2005-2016, doi:10.1016/j.dsr.2005.06.006, 2005.

Basart, S., Pay, M. T., Jorba, O., Pérez, C., Jiménez-Guerrero, P., Schulz, M., and Baldasano, J. M.: Aerosols in the CALIOPE air quality modelling system: evaluation and analysis of PM levels, optical depths and chemical composition over Europe, Atmos. Chem. Phys., 12, 3363-3392, doi:10.5194/acp-12-3363-2012, 2012.

Bergametti, G., Remoudaki, E., Losno, R., Steiner, E., Chatenet, B., and Buat-Menard, P.: Source, transport and deposition of atmospheric phosphorus over the northwestern Mediterranean, J. Atmos. Chem., 14, 501-513, 1992.

Béthoux, J. P., Morin, P., Chaumery, C., Connan, O., Gentili, B., and Ruiz-Pino, D.: Nutrients in the Mediterranean Sea, mass balance and statistical analysis of concentrations with respect to environmental change, Mar. Chem., 63, 155-169, doi:10.1016/S0304-4203(98)00059-0, 1998.

Bonnet, S., and Guieu, C.: Atmospheric forcing on the annual iron cycle in the western Mediterranean Sea: A 1-year survey, J. Geophys. Res. Oceans, 111, C09010, doi:10.1029/2005JC003213, 2006.

Bonnet, S., Guieu, C., Chiaverini, J., Ras, J., and Stock, A.: Effect of atmospheric nutrients on the autotrophic communities in a low nutrient, low chlorophyll system, Limnol. Oceanogr., 50, 1810-1819, 2005.

BGD

9, 8611-8639, 2012

\section{Saharan dust \\ deposition and ocean chlorophyll concentration}

R. Gallisai et al.

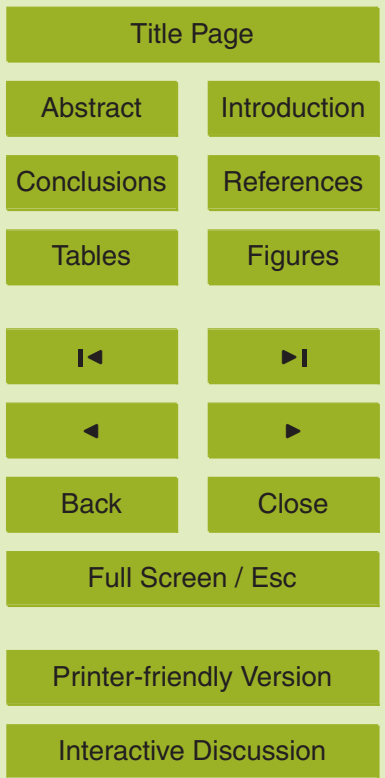


Bosc, E., Bricaud, A., and Antoine, D.: Seasonal and interannual variability in algal biomass and primary production in the Mediterranean Sea, as derived from 4 years of SeaWiFS observations, Global Biogeochem. Cy., 18, GB1005, doi:10.1029/2003GB002034, 2004.

D'Almeida, G. A.: On the variability of desert aerosol radiative characteristics, J. Geophys. Res., 92, 3017-3026, doi:10.1029/JD092iD03p03017, 1987.

D'Ortenzio, F. and D'Alcalà, M. R.: On the trophic regimes of the Mediterranean Sea: A satellite analysis, Biogeosciences, 6, 139-148, doi:10.5194/bg-6-139-2009, 2009.

De Angelis, M. and Gaudichet, A.: Saharan dust deposition over Mont Blanc (French Alps) during the last 30 years, Tellus B, 43 B, 61-75, doi:10.1034/j.1600-0889.1991.00005.x, 1991.

10 Eker-Develi, E., Kideys, A. E., and Tugrul, S.: Role of Saharan dust on phytoplankton dynamics in the northeastern Mediterranean, Mar. Ecol.-Prog. Ser., 314, 61-75, doi:10.3354/meps314061, 2006.

Engelstaedter, S., Tegen, I., and Washington, R.: North African dust emissions and transport, Earth-Sci. Rev., 79, 73-100, doi:10.1016/j.earscirev.2006.06.004, 2006.

Estrada, M.: Primary production in the northwestern Mediterranean, Sci. Mar., 60, 55-64, 1996.

Guerzoni, S., Molinaroli, E., and Chester, R.: Saharan dust inputs to the western Mediterranean Sea: Depositional patterns, geochemistry and sedimentological implications, Deep-Sea Res. Pt. II, 44, 631-654, doi:10.1016/S0967-0645(96)00096-3, 1997.

Guerzoni, S., Chester, R., Dulac, F., Herut, B., Loÿe-Pilot, M. D., Measures, C., Migon, C., Molinaroli, E., Moulin, C., Rossini, P., Saydam, C., Soudine, A., and Ziveri, P.: The role of atmospheric deposition in the biogeochemistry of the Mediterranean Sea, Prog. Oceanogr., 44, 147-190, doi:10.1016/S0079-6611(99)00024-5, 1999.

Guieu, C., Bozec, Y., Blain, S., Ridame, C., Sarthou, G., and Leblond, N.: Impact of high Saharan dust inputs on dissolved iron concentrations in the Mediterranean Sea, Geophys. Res. Lett., 29, 17-11, doi:10.1029/2001GL014454, 2002a.

Guieu, C., Loÿe-Pilot, M. D., Ridame, C., and Thomas, C.: Chemical characterization of the Saharan dust end-member: Some biogeochemical implications for the western Mediterranean Sea, J. Geophys. Res. D: Atmospheres, 107, 4258-4269, doi:10.1029/2001JD000582, 2002b.

Guieu, C., Loÿe-Pilot, M. D., Benyahya, L., and Dufour, A.: Spatial variability of atmospheric fluxes of metals ( $\mathrm{Al}, \mathrm{Fe}, \mathrm{Cd}, \mathrm{Zn}$ and $\mathrm{Pb}$ ) and phosphorus over the whole Mediterranean from
BGD

9, 8611-8639, 2012

\section{Saharan dust \\ deposition and ocean chlorophyll concentration}

R. Gallisai et al.

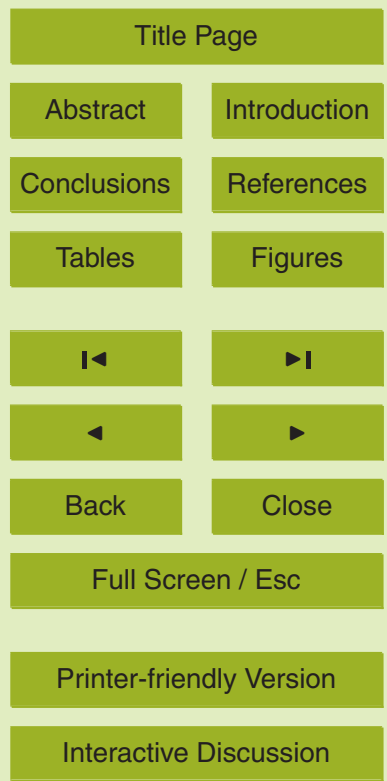


a one-year monitoring experiment: Biogeochemical implications, Mar. Chem., 120, 164-178, 2010.

Haustein, K., Pérez, C., Baldasano, J. M., Müller, D., Tesche, M., Schladitz, A., Esselborn, M., Weinzierl, B., Kandler, K., and Von Hoyningen-Huene, W.: Regional dust model performance 5 during SAMUM 2006, Geophys. Res. Lett., 36, L03812, doi:10.1029/2008GL036463, 2009.

Herut, B., Krom, M. D., Pan, G., and Mortimer, R.: Atmospheric input of nitrogen and phosphorus to the Southeast Mediterranean: Sources, fluxes, and possible impact, Limnol. Oceanogr., 44, 1683-1692, 1999.

Izquierdo, R., Benítez-Nelson, C. R., Masqué, P., Castillo, S., Alastuey, A., and Àvila, A.: Atmospheric phosphorus deposition in a near-coastal rural site in the NE Iberian Peninsula and its role in marine productivity, Atmos. Environ., 49, 361-370, doi:10.1016/j.atmosenv.2011.11.007, 2012.

Jiménez-Guerrero, P., Pérez, C., Jorba, O., and Baldasano, J. M.: Contribution of Saharan dust in an integrated air quality system and its on-line assessment, Geophys. Res. Lett., 35, L03814, doi:10.1029/2007GL031580, 2008.

Klein, C., Dolan, J. R., and Rassoulzadegan, F.: Experimental examination of the effects of rainwater on microbial communities in the surface layer of the NW Mediterranean Sea, Mar. Ecol. Prog. Ser., 158, 41-50, doi:10.3354/meps158041, 1997.

Kouvarakis, G., Mihalopoulos, N., Tselepides, A., and Stavrakakis, S.: On the importance of atmospheric inputs of inorganic nitrogen species on the productivity of the Eastern Mediterranean sea, Global Biogeochem. Cy., 15, 805-817, doi:10.1029/2001GB001399, 2001.

Kubilay, N., Nickovic, S., Moulin, C., and Dulac, F.: An illustration of the transport and deposition of mineral dust onto the eastern Mediterranean, Atmos. Environ., 34, 1293-1303, doi:10.1016/S1352-2310(99)00179-X, 2000.

Lekunberri, I., Lefort, T., Romero, E., Vázquez-Domínguez, E., Romera-Castillo, C., Marrasé, C., Peters, F., Weinbauer, M., and Gasol, J. M.: Effects of a dust deposition event on coastal marine microbial abundance and activity, bacterial community structure and ecosystem function, J. Plankton Res., 32, 381-396, doi:10.1093/plankt/fbp137, 2010.

Loÿe-Pilot, M. D., Martin, J. M., and Morelli, J.: Atmospheric input of inorganic nitrogen to the Western Mediterranean, Biogeochemistry, 9, 117-134, doi:10.1007/BF00692168, 1990.

Mamane, Y., Ganor, E., and Donagi, A. E.: Aerosol composition of urban and desert origin in the eastern Mediterranean. II. Deposition of large particles, Water Air Soil Poll., 18, 475-484, doi:10.1007/BF02426055, 1982.

BGD

9, 8611-8639, 2012

\section{Saharan dust \\ deposition and ocean chlorophyll concentration}

R. Gallisai et al.

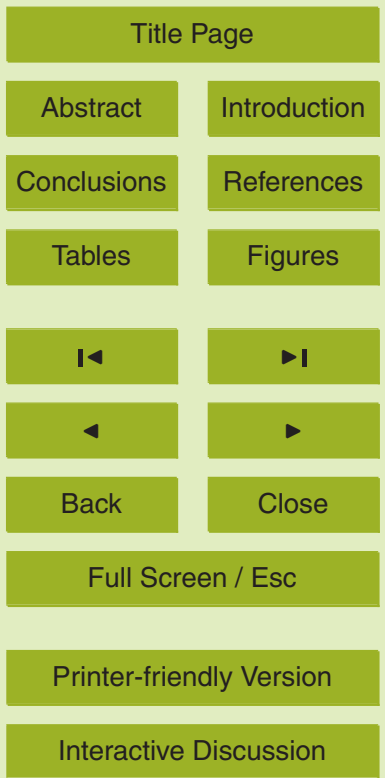


Marañón, E., Fernández, A., Mouriño-Carballido, B., Martínez-García, S., Teira, E., Cermeño, P., Chouciño, P., Huete-Ortega, M., Fernández, E., Calvo-Díaz, A., Morán, X. A. G., Bode, A., Moreno-Ostos, E., Varela, M. M., Patey, M. D., and Achterberg, E. P.: Degree of oligotrophy controls the response of microbial plankton to Saharan dust, Limnol. Oceanogr., 55, 2339$5 \quad 2352,2010$.

Markaki, Z., Oikonomou, K., Kocak, M., Kouvarakis, G., Chaniotaki, A., Kubilay, N., and Mihalopoulos, N.: Atmospheric deposition of inorganic phosphorus in the Levantine Basin, eastern Mediterranean: Spatial and temporal variability and its role in seawater productivity, Limnol. Oceanogr., 48, 1557-1568, doi:10.1029/2000JD000291, 2003.

10 Markaki, Z., Loÿe-Pilot, M. D., Violaki, K., Benyahya, L., and Mihalopoulos, N.: Variability of atmospheric deposition of dissolved nitrogen and phosphorus in the Mediterranean and possible link to the anomalous seawater N/P ratio, Mar. Chem., 120, 187-194, doi:10.1016/j.marchem.2008.10.005, 2010.

Migon, C. and Sandroni, V.: Phosphorus in rainwater: Partitioning inputs and impact on the 15 surface coastal ocean, Limnol. Oceanogr., 44, 1160-1165, 1999.

Mona, L., Amodeo, A., Pandolfi, M., and Pappalardo, G.: Saharan dust intrusions in the Mediterranean area: Three years of Raman lidar measurements, J. Geophys. Res.-Atmos., 111, D16203, doi:10.1029/2005JD006569, 2006.

Morales-Baquero, R., Pulido-Villena, E., and Reche, I.: Atmospheric inputs of phosphorus and $20 \quad$ nitrogen to the southwest Mediterranean region: Biogeochemical responses of high mountain lakes, Limnol. Oceanogr., 51, 830-837, 2006a.

Morales-Baquero, R., Pulido-Villena, E., Romera, O., Ortega-Retuerta, E., Conde-Porcuna, J. M., Pérez-Martínez, C., and Reche, I.: Significance of atmospheric deposition to freshwater ecosystems in the southern Iberian Peninsula, Limnetica, 25, 171-180, 2006b.

Moreno, T., Querol, X., Castillo, S., Alastuey, A., Cuevas, E., Herrmann, L., Mounkaila, M., Elvira, J., and Gibbons, W.: Geochemical variations in aeolian mineral particles from the Sahara-Sahel Dust Corridor, Chemosphere, 65, 261-270, doi:10.1016/j.chemosphere.2006.02.052, 2006.

Moulin, C., Lambert, C. E., Dayan, U., Masson, V., Ramonet, M., Bousquet, P., Legrand, M., 30 Balkanski, Y. J., Guelle, W., Marticorena, B., Bergametti, G., and Dulac, F.: Satellite climatology of African dust transport in the Mediterranean atmosphere, J. Geophys. Res. D, 103, 13137-13144, doi:10.1029/98JD00171, 1998.

\section{BGD}

9, 8611-8639, 2012

\section{Saharan dust \\ deposition and ocean chlorophyll concentration}

R. Gallisai et al.

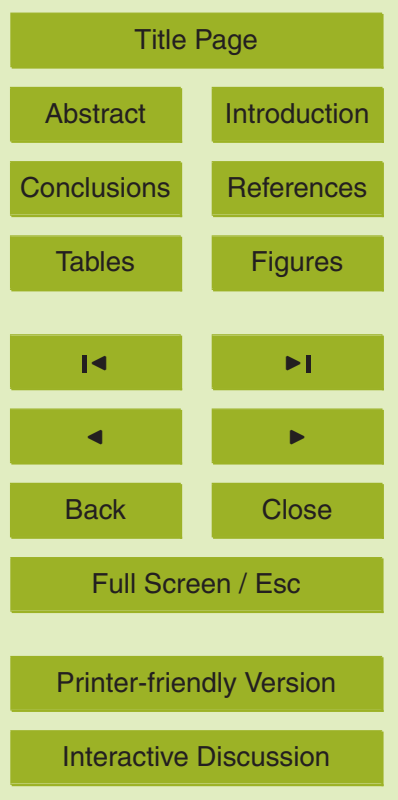


Papanastasiou, D. K., Poupkou, A., Katragkou, E., Amiridis, V., Melas, D., Mihalopoulos, N., Basart, S., Pérez, C., and Baldasano, J. M.: An Assessment of the Efficiency of Dust Regional Modelling to Predict Saharan Dust Transport Episodes, Advances in Meteorology, 2010, Art. ID 154368, 9 pp., doi:10.1155/2010/154368, 2010.

5 Papayannis, A., Amiridis, V., Mona, L., Tsaknakis, G., Balis, D., Bösenberg, J., Chaikovski, A., De Tomasi, F., Grigorov, I., Mattis, I., Mitev, V., Müller, D., Nickovic, S., Pérez, C., Pietruczuk, A., Pisani, G., Ravetta, F., Rizi, V., Sicard, M., Trickl, T., Wiegner, M., Gerding, M., Mamouri, R. E., D'Amico, G., and Pappalardo, G.: Systematic lidar observations of Saharan dust over Europe in the frame of EARLINET (2000-2002), J. Geophys. Res.-Atmos., 113, D10204, doi:10.1029/2007JD009028, 2008.

Pappalardo, G., Amodeo, A., Amoruso, S., Mona, L., Pandolfi, M., and Cuomo, V.: One year of tropospheric lidar measurements of aerosol extinction and backscatter, Ann. Geofis., 46, 401-414, 2003.

Pay, M. T., Piot, M., Jorba, O., Gassó, S., Gonçalves, M., Basart, S., Dabdub, D., Jiménez-Guerrero, P., and Baldasano, J. M.: A full year evaluation of the CALIOPEEU air quality modeling system over Europe for 2004, Atmos. Environ., 44, 3322-3342, doi:10.1016/j.atmosenv.2010.05.040, 2010.

Pay, M. T., Jiménez-Guerrero, P., Jorba, O., Basart, S., Querol, X., Pandolfi, M., and Baldasano, J. M.: Spatio-temporal variability of concentrations and speciation of particulate matter across Spain in the CALIOPE modeling system, Atmos. Environ., 46, 376-396, doi:10.1016/j.atmosenv.2011.09.049, 2012.

Pérez, C., Nickovic, S., Baldasano, J. M., Sicard, M., Rocadenbosch, F., and Cachorro, V. E.: A long Saharan dust event over the western Mediterranean: Lidar, Sun photometer observations, and regional dust modeling, J. Geophys. Res.-Atmos., 111, D15214, doi:10.1029/2005JD006579, 2006a.

Pérez, C., Nickovic, S., Pejanovic, G., Baldasano, J. M., and Özsoy, E.: Interactive dust-radiation modeling: A step to improve weather forecasts, J. Geophys. Res.-Atmos., 111, D16206, doi:10.1029/2005JD006717, 2006b.

Pulido-Villena, E., Wagener, T., and Guieu, C.: Bacterial response to dust pulses in the western Mediterranean: Implications for carbon cycling in the oligotropic ocean, Global Biogeochem. Cy., 22, GB1020, doi:10.1029/2007GB003091, 2008.

Pulido-Villena, E., Rrolle, V., and Guieu, C.: Transient fertilizing effect of dust in P-deficient LNLC surface ocean, Geophys. Res. Lett., 37, L01603, doi:10.1029/2009GL041415, 2010.
BGD

$9,8611-8639,2012$

\section{Saharan dust \\ deposition and ocean chlorophyll concentration}

R. Gallisai et al.

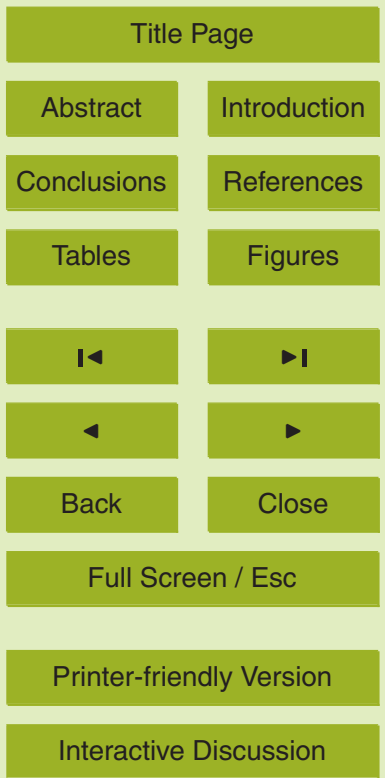


Pye, K.: Aeolian dust transport and deposition over Crete and adjacent parts of the Mediterranean Sea, Earth Surf. Proc. Land., 17, 271-288, doi:10.1002/esp.3290170306, 1992.

Querol, X., Pey, J., Pandolfi, M., Alastuey, A., Cusack, M., Pérez, N., Moreno, T., Viana, M., Mihalopoulos, N., Kallos, G., and Kleanthous, S.: African dust contributions to mean ambient PM10 mass-levels across the Mediterranean Basin, Atmos. Environ., 43, 4266-4277, doi:10.1016/j.atmosenv.2009.06.013, 2009.

Ridame, C. and Guieu, C.: Saharan input of phosphate to the oligotrophic water of the open western Mediterranean sea, Limnol. Oceanogr., 47, 856-869, 2002.

Romero, E., Peters, F., Marrasé, C., Guadayol, T., Gasol, J. M., and Weinbauer, M. G.: Coastal Mediterranean plankton stimulation dynamics through a dust storm event: An experimental simulation, Estuar. Coast. Shelf S., 93, 27-39, doi:10.1016/j.ecss.2011.03.019, 2011.

Sandroni, V., Raimbault, P., Migon, C., Garcia, N., and Gouze, E.: Dry atmospheric deposition and diazotrophy as sources of new nitrogen to northwestern Mediterranean oligotrophic surface waters, Deep-Sea Res. Pt. I, 54, 1859-1870, doi:10.1016/j.dsr.2007.08.004, 2007.

Sicard, M., Rocadenbosch, F., Reba, M. N. M., Comerón, A., Tomás, S., García-Vízcaino, D., Batet, O., Barrios, R., Kumar, D., and Baldasano, J. M.: Seasonal variability of aerosol optical properties observed by means of a Raman lidar at an EARLINET site over Northeastern Spain, Atmos. Chem. Phys., 11, 175-190, doi:10.5194/acp-11-175-2011, 2011.

Singer, A., Ganor, E., Dultz, S., and Fischer, W.: Dust deposition over the Dead Sea, J. Arid Environ., 53, 41-59, doi:10.1006/jare.2002.1023, 2003.

Tegen, I. and Lacis, A. A.: Modeling of particle size distribution and its influence on the radiative properties of mineral dust aerosol, J. Geophys. Res-Atmos., 101, 19237-19244, doi:10.1029/95JD03610, 1996.

Ternon, E., Guieu, C., Ridame, C., L'Helguen, S., and Catala, P.: Longitudinal variability of the biogeochemical role of Mediterranean aerosols in the Mediterranean Sea, Biogeosciences, 8, 1067-1080, doi:10.5194/bg-8-1067-2011, 2011.

Theodosi, C., Markaki, Z., and Mihalopoulos, N.: Iron speciation, solubility and temporal variability in wet and dry deposition in the Eastern Mediterranean, Mar. Chem., 120, 100-107, doi:10.1016/j.marchem.2008.05.004, 2010.

30 Thingstad, T. F., Krom, M. D., Mantoura, R. F. C., Flaten, C. A. F., Groom, S., Herut, B., Kress, N., Law, C. S., Pasternak, A., Pitta, P., Psarra, S., Rassoulzadegan, F., Tanaka, T., Tselepides, A., Wassmann, P., Woodward, E. M. S., Riser, C. W., Zodiatis, C., and Zohary, T.: Nature
BGD

9, 8611-8639, 2012

\section{Saharan dust \\ deposition and ocean chlorophyll concentration}

R. Gallisai et al.

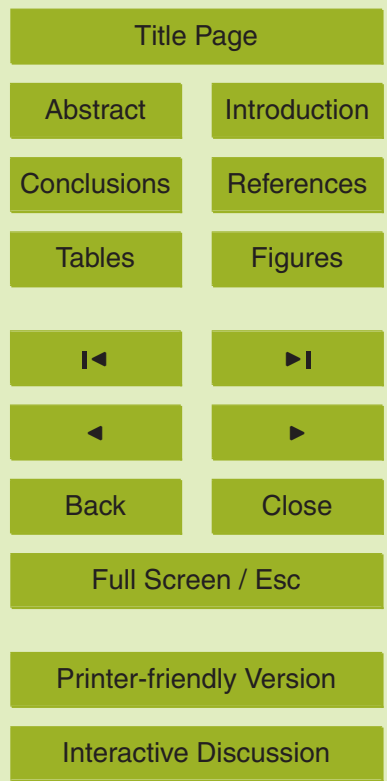


of phosphorus limitation in the ultraoligotrophic eastern Mediterranean, Science, 309, 10681071, doi:10.1126/science.1112632, 2005.

Todd, M. C., Bou Karam, D., Cavazos, C., Bouet, C., Heinold, B., Baldasano, J. M., Cautenet, G., Koren, I., Pérez, C., Solmon, F., Tegen, I., Tulet, P., Washington, R., and Zakey, A.: Quantifying uncertainty in estimates of mineral dust flux: An intercomparison of model performance over the Bodélé depression, northern Chad, J. Geophys. Res-Atmos., 113, D24107, doi:10.1029/2008JD010476, 2008.

Volpe, G., Banzon, V. F., Evans, R. H., Santoleri, R., Mariano, A. J., and Sciarra, R.: Satellite observations of the impact of dust in a low-nutrient, lowchlorophyll region: Fertilization or

\section{BGD}

9, 8611-8639, 2012

\section{Saharan dust \\ deposition and ocean chlorophyll concentration}

R. Gallisai et al.

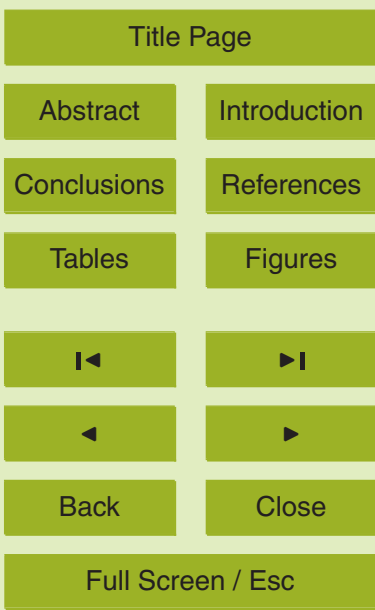

Printer-friendly Version

Interactive Discussion 


\section{BGD}

9, 8611-8639, 2012

\section{Saharan dust \\ deposition and ocean chlorophyll concentration}

R. Gallisai et al.

Table 1. Results of dust deposition impact on chlorophyll variability.

\begin{tabular}{lll}
\hline & Chl vs. dust & Chl vs. dust (detrended) \\
\hline All 95 areas & $11.5 \%$ & $4.6 \%$ \\
South Baleares & $1.8 \%$ & $6.0 \%$ \\
Tyrrhenian Sea & $3.0 \%$ & $6.0 \%$ \\
Central Mediterranean & $18.7 \%$ & $5.2 \%$ \\
\hline
\end{tabular}

Title Page

Abstract

Conclusions

Tables

14

4

Back

Full Screen / Esc

Printer-friendly Version

Interactive Discussion 


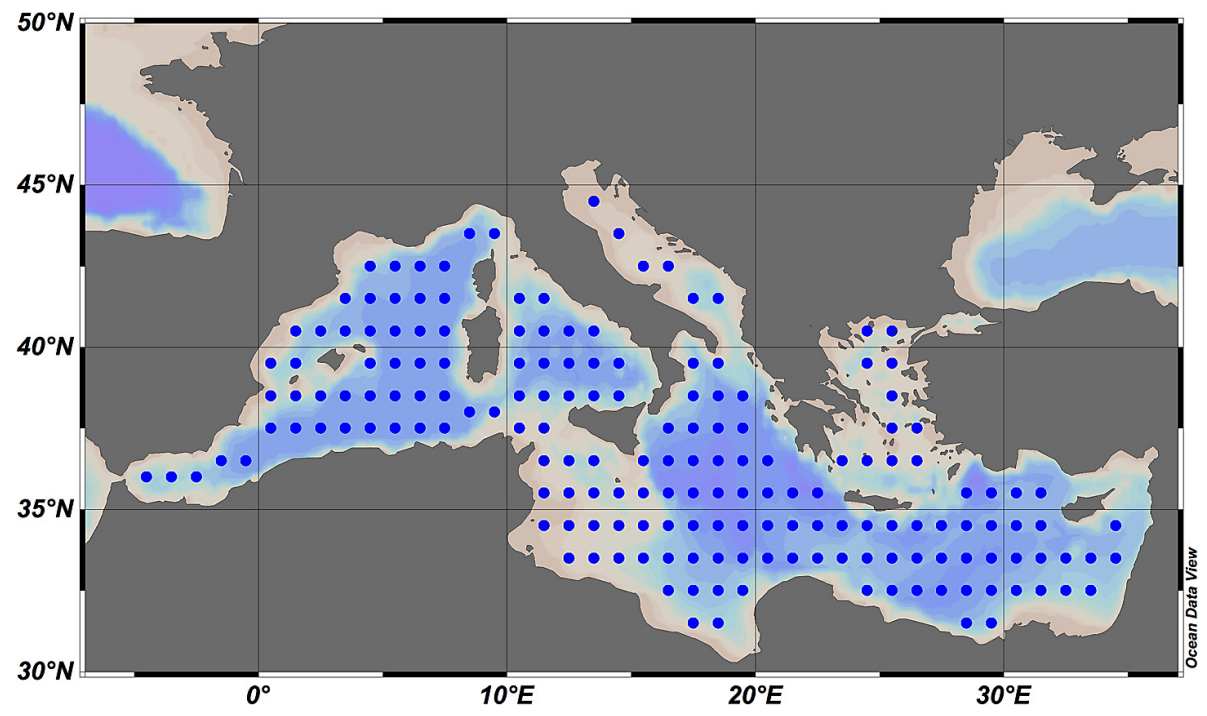

\section{BGD}

9, 8611-8639, 2012

\section{Saharan dust deposition and ocean chlorophyll concentration}

R. Gallisai et al.

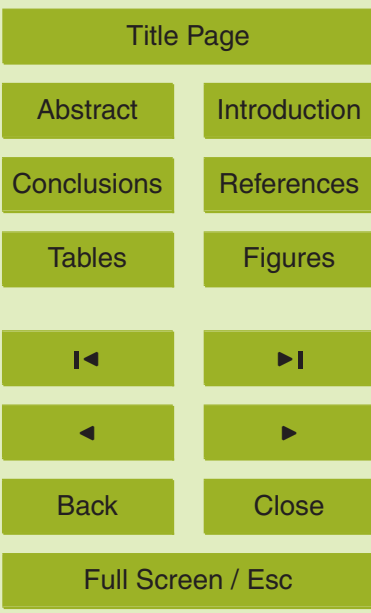

Fig. 1. Map that shows the 179 areas, $1^{\circ} \times 1^{\circ}$ in size, used for the chlorophyll and Saharan dust deposition data analyses.

\section{Full Screen / Esc}

Printer-friendly Version

Interactive Discussion 


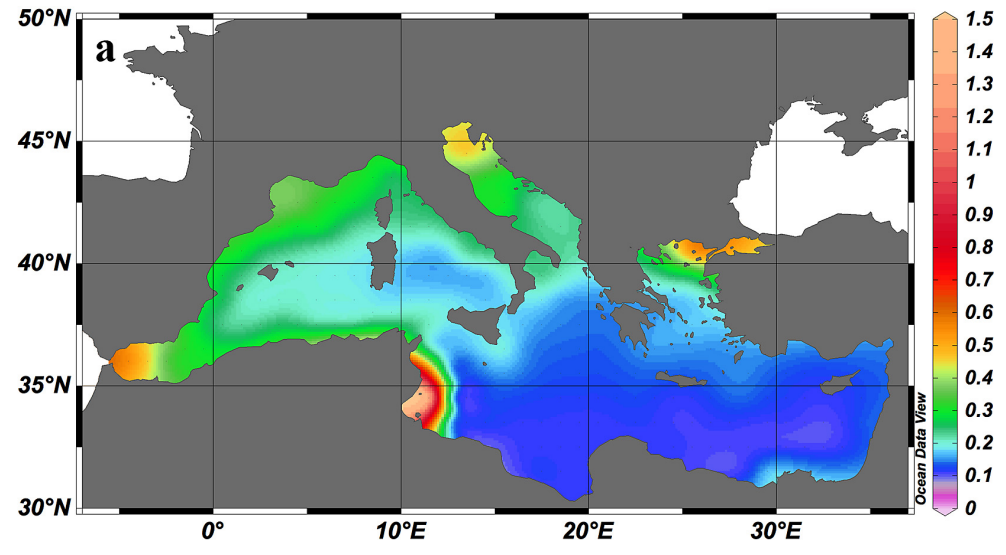

\section{BGD}

9, 8611-8639, 2012

\section{Saharan dust \\ deposition and ocean chlorophyll concentration}

R. Gallisai et al.

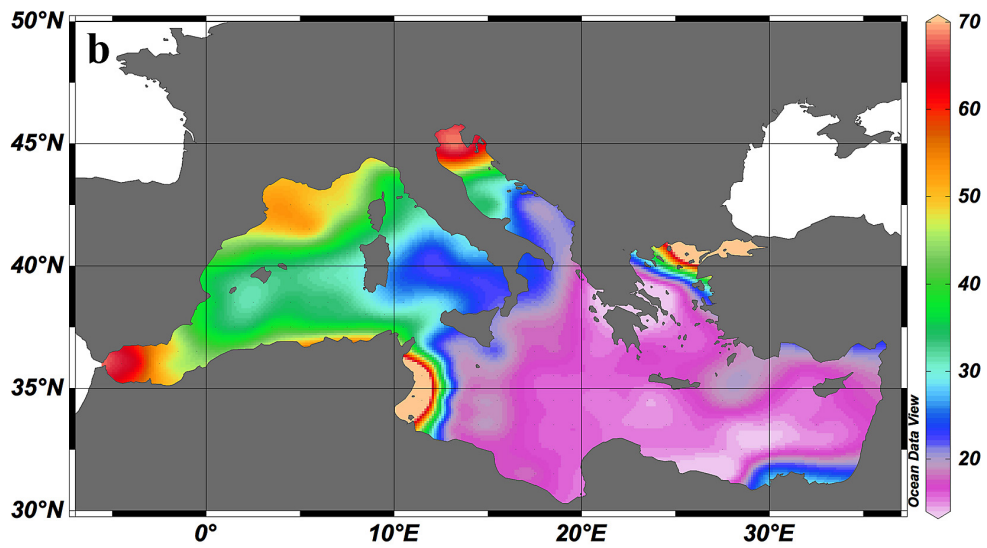

Title Page

Abstract

Introduction

Conclusions

References

Tables

Figures

14

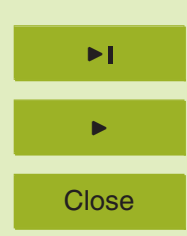

Back

Full Screen / Esc

Printer-friendly Version

Interactive Discussion 


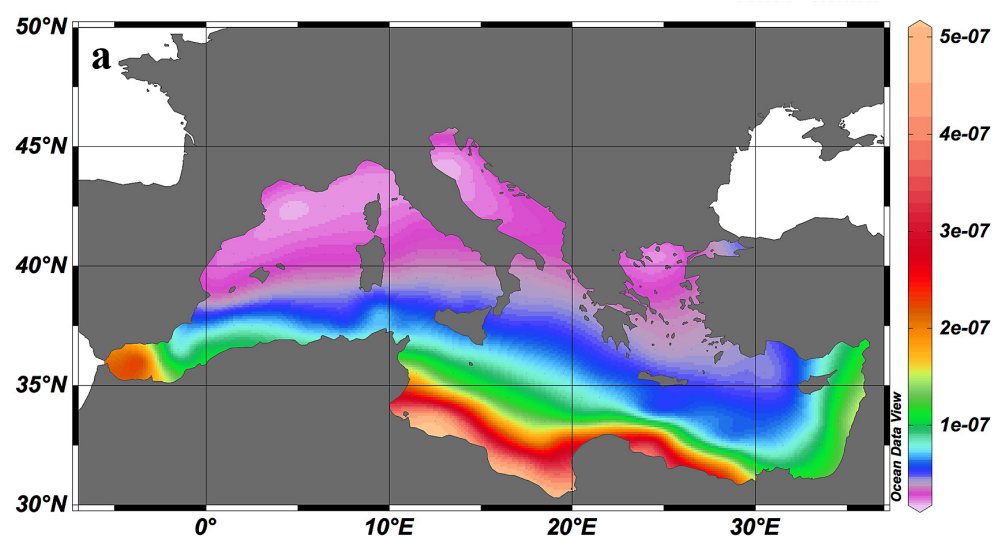

BGD

9, 8611-8639, 2012

\section{Saharan dust \\ deposition and ocean chlorophyll concentration}

R. Gallisai et al.

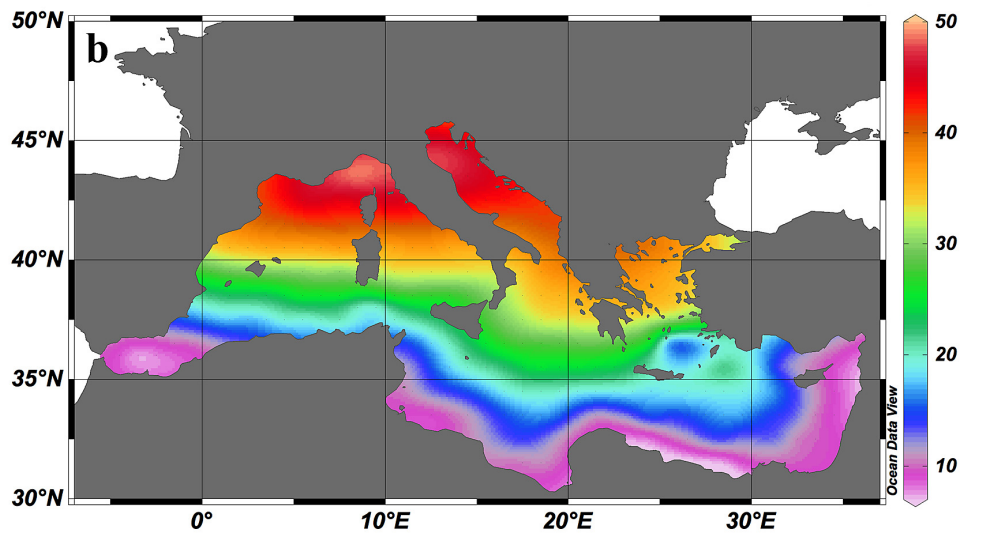

Title Page

Abstract

Introduction

Conclusions

References

Tables

Figures

14

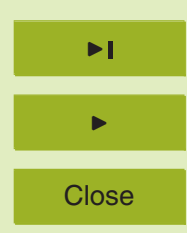

Back

Close

Full Screen / Esc

Printer-friendly Version

Interactive Discussion 

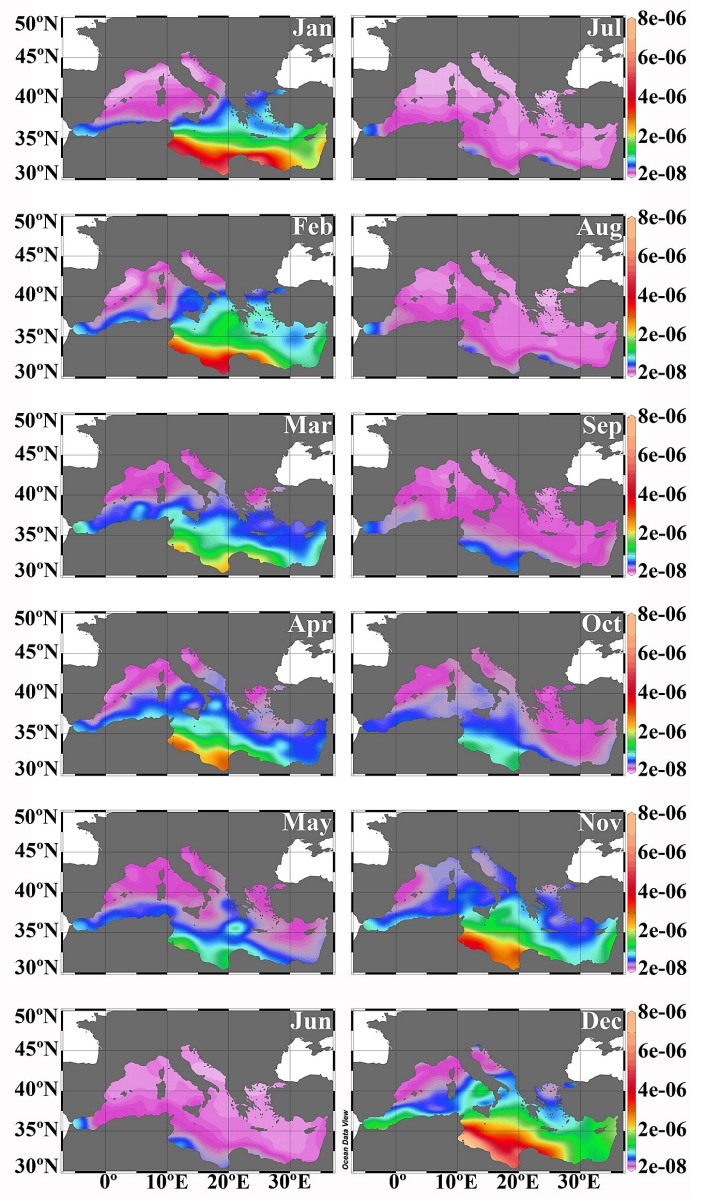

Fig. 4. Monthly climatic modeled deposition (2000-2007) in the Mediterranean Sea from BSCDREAM8b.

\section{BGD}

9, 8611-8639, 2012

\section{Saharan dust \\ deposition and ocean chlorophyll concentration}

R. Gallisai et al.

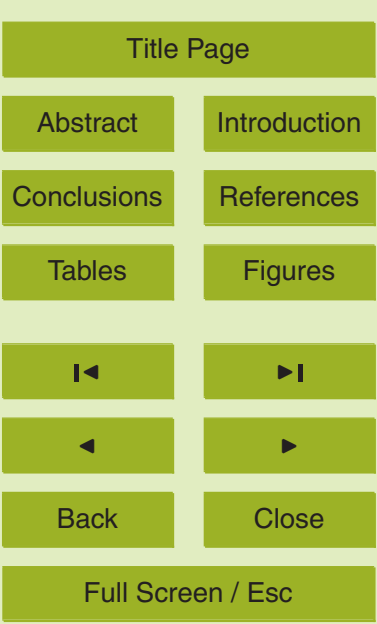

Printer-friendly Version

Interactive Discussion 


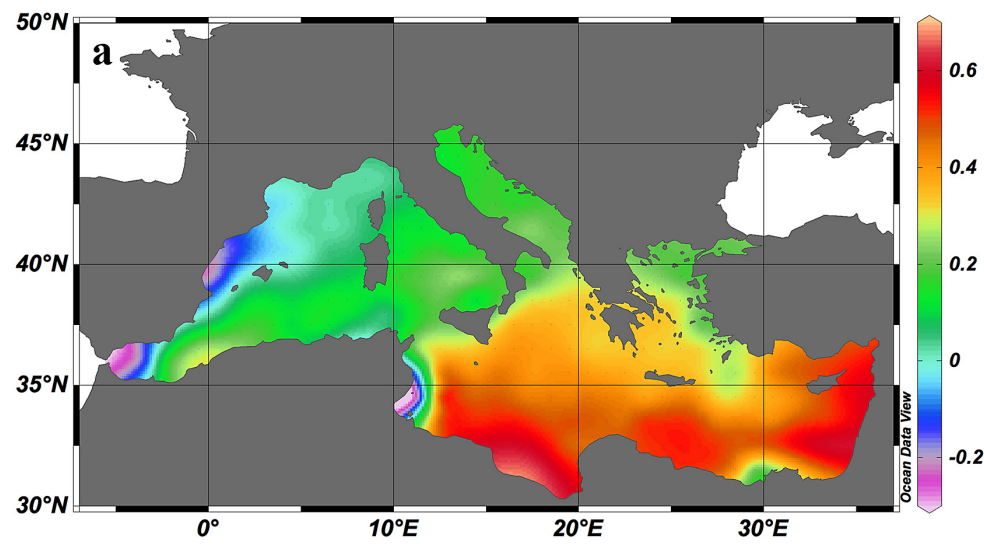

BGD

9, 8611-8639, 2012

\section{Saharan dust \\ deposition and ocean chlorophyll concentration}

R. Gallisai et al.

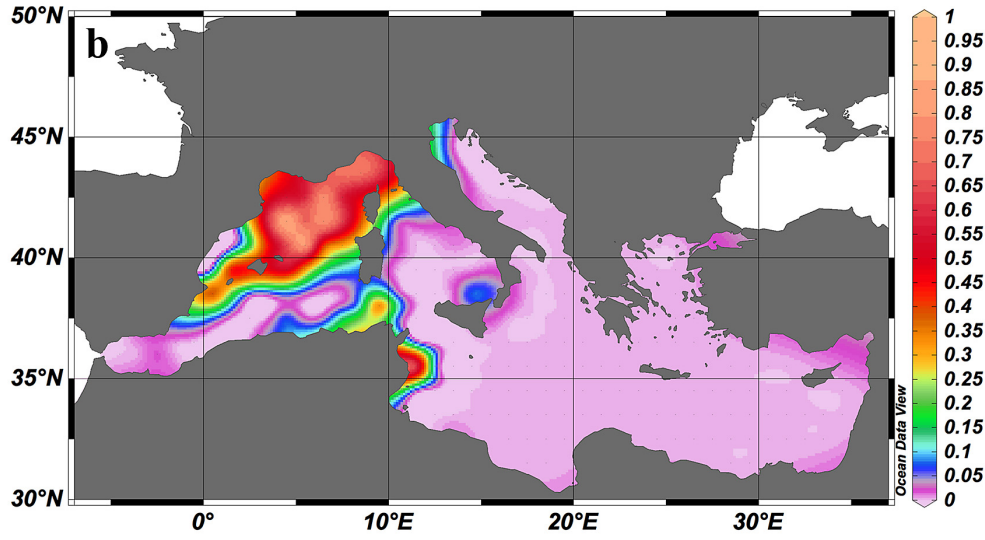

Title Page

\section{Abstract}

Conclusions

\section{Tables}

14

4

Back

\section{Full Screen / Esc}

Printer-friendly Version
Fig. 5. Chlorophyll and dust deposition correlation at time lag 0 (a) and the corresponding p-level statistical significance (b). 

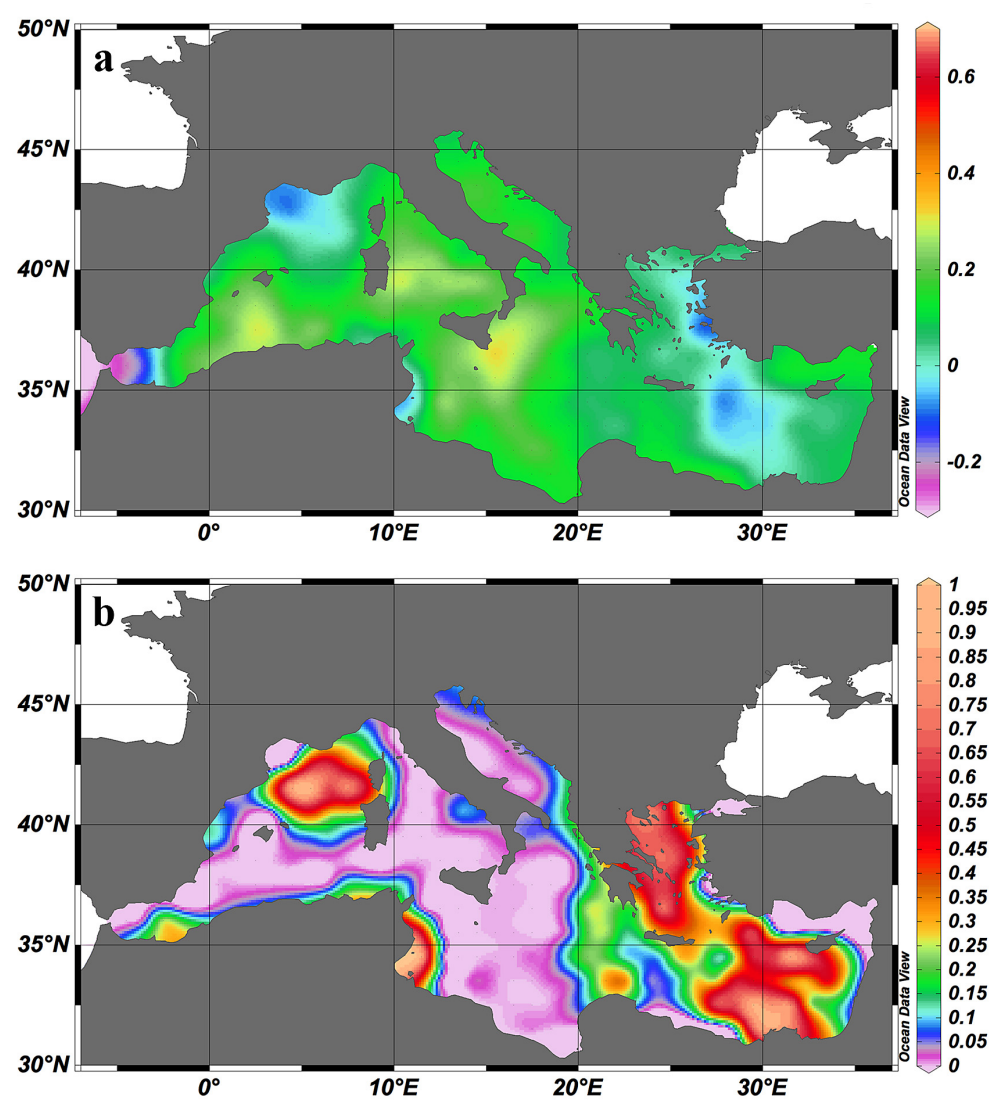

BGD

9, 8611-8639, 2012

\section{Saharan dust \\ deposition and ocean chlorophyll concentration}

R. Gallisai et al.

Title Page

\section{Abstract}

Conclusions

\section{Tables}

14

4

Back
Introduction

References

Figures

$\rightarrow 1$

Close

\section{Full Screen / Esc}

Printer-friendly Version

Interactive Discussion 

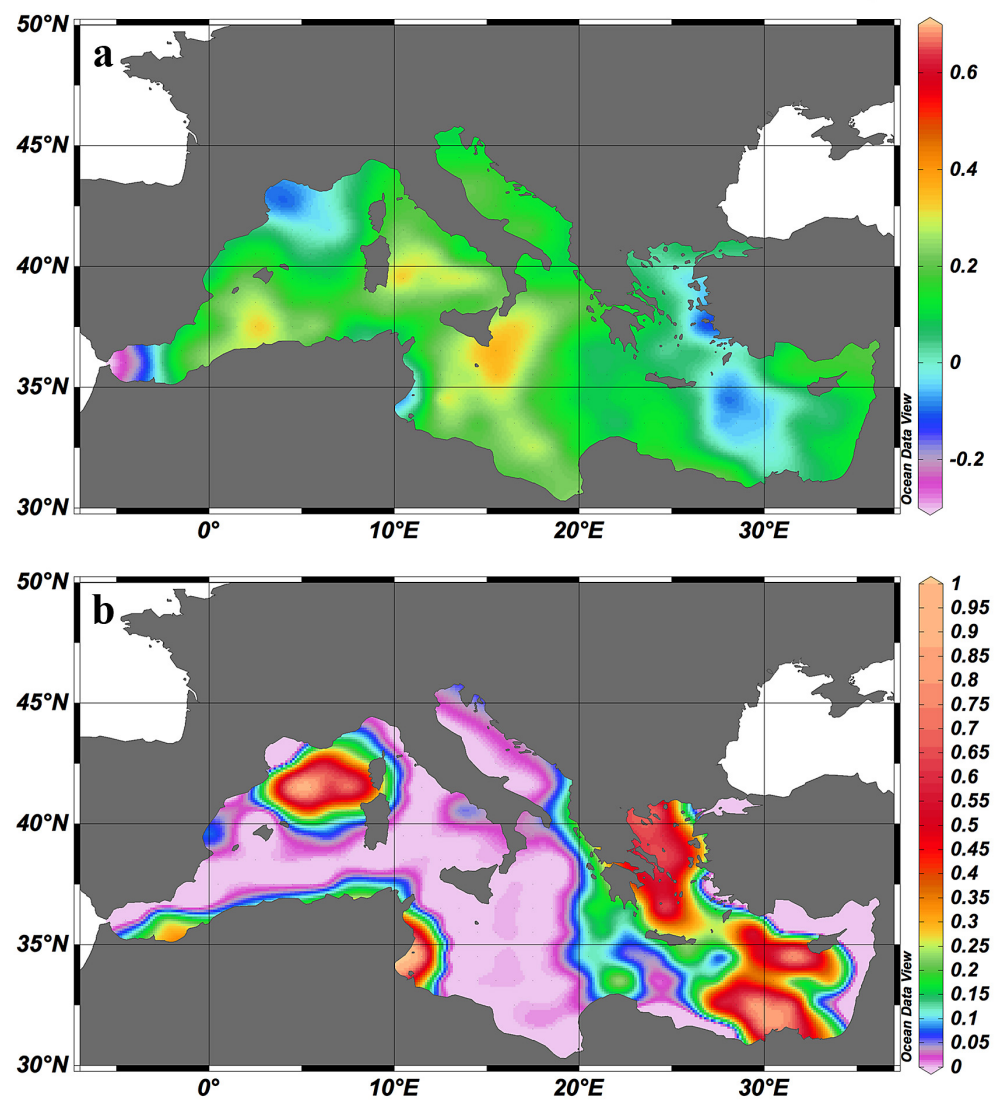

BGD

9, 8611-8639, 2012

\section{Saharan dust \\ deposition and ocean chlorophyll concentration}

R. Gallisai et al.

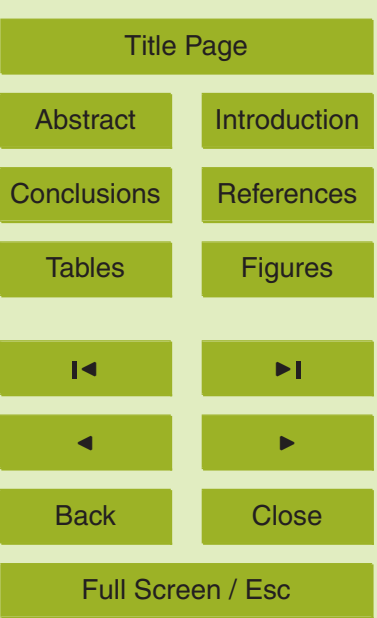

Fig. 7. Same as Fig. 5 but for the correlation between seasonally detrended chlorophyll and seasonally detrended deposition.

Printer-friendly Version

Interactive Discussion 


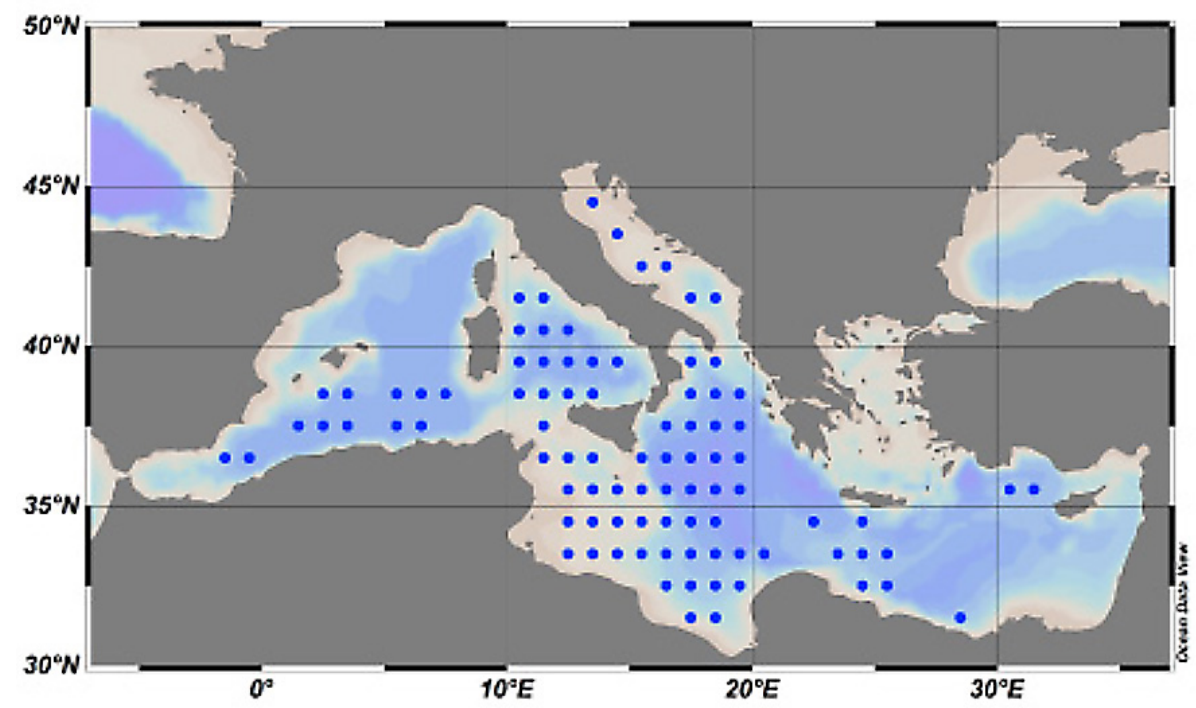

Fig. 8. Map that shows the 95 areas with positive and statistically significant $(p<0.05)$ correlations, in both chlorophyll vs. dust deposition and seasonally detrended chlorophyll vs. seasonally detrended deposition.

\section{BGD}

9, 8611-8639, 2012

\section{Saharan dust \\ deposition and ocean chlorophyll concentration}

R. Gallisai et al.

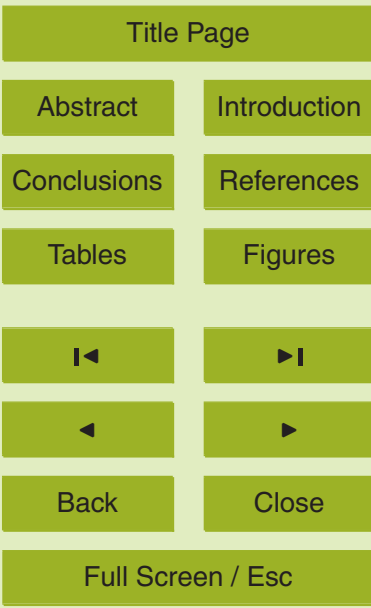

Printer-friendly Version

Interactive Discussion 